\title{
Leper Survey of the Arabian Peninsula
}

W. H. Storm.

In the 1935 annual report of the British Empire Leprosy Relief Association, entitled “ Worse than Slavery," we read:

(1) "It is not an exaggeration to say that of all diseases leprosy is the most terrible-not killing, but mutilating by slow degrees, and ultimately destroying even the semblance of a human being. Men, women and children become moulded into that ghastly form in which personality, sex and age are blotted out, and the victim becomes a mere caricature of humanity."

(2) "Few realize that of the world's population at least one person in every 370 suffers from leprosy, and that in the British Empire there are at least two million sufferers, some indeed put the number much higher."

The object of the Council of the British Empire Leprosy Relief Association is the banishment of leprosy from the Empire. The purpose of the International Leprosy Association is to rid the world of Leprosy.

The burden of such a task is great. An educated public opinion is necessary. "Much has already been accomplished as the result of continued research and widespread carefully conducted surveys; to our knowledge has come a deeper realization of the extent and gravity of the scourge, and of the immense effort that is necessary to deal with it adequately. Only a small percentage of the areas infected by leprosy are at present touched; hundreds of sufferers are being refused admission for lack of means and accommodation; devoted doctors and nurses are overburdened with labour."

It was in view of all of this that in connection with my recent tour across and around Arabia I attempted a survey of the entire Peninsula from the point of view of leprosy bearing in mind chiefly its incidence and the form of the disease.

In French text books leprosy is known by the term "Lepres de Arabes".

Mohammed is supposed to have said "Flee from the leper as you would flee from a lion". This expresses in no small measure the attitude of Mohammedans everywhere. There is also a general fatalistic attitude as expressed by Dr. Mahmud, Medical Director of Hedjaz Government Medical Service in Taif_- "No cure ".

The methods we used were carried out in connection with our general routine medical and surgical work. I examined 
every suspicious case. As soon as I arrived at a town or a village $I$ let it be known that I was especially interested in skin diseases. News in the Orient spreads with incredible speed. Soon all forms of skin diseases would appear. I would then trace all contacts of the suspected leper case, especially among his children and friends. Here it must be noted that inasmuch as schools do not exist it was impossible to examine children in any large number. The methods of examination were :

(a) General impressions.

(b) History.

(c) Physical findings.

(d) Nasal smear.

(e) Wade incision smear.

$(f)$ Occasional excision smear.

$I$ at once realized the inadequacy of this method, but when one considers the political situations, difficulties of travel, and non-cooperation or entire lack of the local medical force, I believe it was and is the only possible method at present for a leper survey of Arabia.

Our time was spent as follows:

Six weeks were spent in Taif. Three weeks in Asir. Fifteen days in Aden. One month in Hadramaut. Two months in Dhufar.

We visited many villages en route and were in constant contact for nearly ten months with native peoples.

The medical statistics for the whole tour were as follows :

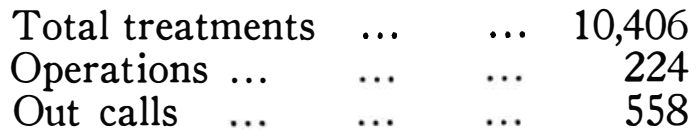

For the purpose of this survey, I have divided the Arabian Peninsula into the following sections. They are, for the main part, political identities and therefore serve as natural boundaries for any survey.

NEJD.

HEDJAZ.

ASIR.

YEMEN.
ADEN PROTECTORATE.

MAKALLA-HADRAMAUT.

BILAD MAHARA.

DHUFAR.
OMAN.

BAHRAIN.

KUWAIT.

Nejd.

Leprosy is practically not seen at all among Nejd bedouins. I found one case among the women of the Royal Court in Ryad. Also one Hadji (pilgrim), obviously a lepe was seen on the streets of Ryad. I have consulted with Dr. Dame, of the American Mission in Bahrain, who has done extensive travelling in Nejd, and he verifies these findings - namely that leprosy is only very occasionally found in this section. 


\section{Hedjaz.}

The population of Hedjaz is less purely Arab. Turkish domination and Sherifan Rule brought in influences from many outside sources. The war and post-war periods increased those already existing and added new ones. Mecca and Medina (the Moslem Holy Cities) with their yearly influx of thousands and thousands of pilgrims are confronted with numerous public health and medical problems. Climate, native methods of living, housing, sanitation and water supply do not help in the least to solve' these problems. Rather they enhance them. One hesitates to think what might occur during a Hadj season if it were not for an effective quarantine. The local quarantine services at Jiddah and Yembo leave much to be desired. Patah says about $50 \%$ of the pilgrims come through the seaports of Jiddah and Yembo. To reach these ports the pilgrims must pass either the International Quarantine Station at Kameran or the Egyptian Quarantine Station at Tor. Both of these Stations are adequately manned, capable of caring for thousands of pilgrims at a time, and maintain a most effective system of quarantine.

Patah reports :

$\begin{array}{ccc}\text { Year } & \text { Pilgrims } & \text { Lepers Reported } \\ 1930 & 100,000 & 7 \\ 1931 & 50,000 & 2 \\ 1932 & 40,000 & 0\end{array}$

Dr. Abdul Rahman, in Meccan Dispensary, presents the following report. (Statistics given me by Charge d'Affairs of Jiddah).

$\begin{array}{ccccc}\text { Haj 1353-1934. } & & & \text { No. Cases. } & \text { Lepers } \\ \text { Javanese } & \ldots & \ldots & 4,691 & 4 \\ \text { Malayan } & \ldots & \ldots & 441 . & 0 \\ \text { Arabs } \ldots & \ldots & \ldots & 552 & 1\end{array}$

The British Consulate for the year 1934 gives statistics of approximately 38,000 cases treated and only 4 lepers found.

My own statistics :

\begin{tabular}{llllcc} 
Place & \multicolumn{4}{c}{ No. Treated } & Lepers \\
Taif & $\ldots$ & $\ldots$ & $\ldots$ & 4,475 & 17 \\
Jiddah & $\ldots$ & $\ldots$ & $\ldots$ & 136 & 1 \\
Yembo & $\ldots$ & $\ldots$ & $\ldots$ & 100 & 1
\end{tabular}

One of the chief difficulties in such a problem, especially when introduced by one from the outside, is the hopeless attitude assumed by the Medical Department of the Saudia Government. In my first conversation with the Director, the only responses he gave were- " there isn't any here ""No cure". Two of the proven cases in Taif were of 
infectious type and were found to be bakers in the bazaar. On reporting this to the local authorities, they could see no concern for alarm.

Although the incidence is not great, there is enough present to create a problem. It would not take a great deal to eradicate it completely from the country, provided, of course, the quarantine services by sea continue their excellent work and the Saudia Government whips into action an adequate service for the land pilgrims. The situation is quite hopeful but must be attacked through the existing Saudia Medical Service.

Asir.

This small buffer state lying between Hedjaz and Yemen is now under Saudia Rule. The same general problems that confront Hedjaz apply here.

In treating 2,092 cases I saw only 4 positive lepers and only one of these could be said to be infectious. Here the people are the poorest to be found anywhere in Arabia and medical conditions are very bad. Certainly leprosy is not a problem here and can be practically dismissed except that from an economic and sociological point of view it is fertile soil for leprosy to spread if once implanted.

\section{Yemen.}

Yemen in many respects is the most closed of all sections of Arabia to the foreigner. I had to be content with the information gathered during my coastal trip by camel caravan from Ibn Abbas to Hodeidah and during my stay in Hodeidah. I interviewed various influential men and especially the Italian Doctor in Hodeidah. Much information was also gained at a later date from the staff of the Ian Keith Falconer Mission Hospital in Sheikh Othman and the frontier Secretary of the Residency in Aden. Here we have what is undoubtedly our biggest problem concerning leprosy in the whole peninsula.

There is without doubt a definite area in Southeast Yemen centering around Taiz. The exact geographical boundaries of this area and the extent of the infection is as yet unknown. Reported cases of entire villages and families with six to seven victims within the family came to my attention. Practically all of the cases treated in the Leprosarium in Sheikh Othman come from these Montane and sub-Montane regions in south Yemen bordering on Aden Protectorate. It is general knowledge that this condition exists and equally common knowledge that except for the efforts in Sheikh Othman nothing is being done. 


\section{Aden Protectorate.}

The situation here is so closely tied up with Yemen that they really become one. In the Leprosy Review, January, 1934, there appeared two splendid informative articles-

(1) Aden and its Leprosy Problem-by E. S. Phipson.

(2) Leprosy Work in Aden Settlement-

by P. W. R. Petrie.

Whenever a work is fashioned on a compromise between humanity and expediency it will by the very nature of the case fall far short of adequacy.

The work done by the faithful workers at the Leprosarium and the attempt of the Aden Leper Board to meet the demands made by those lepers who come into Aden from the Hinterland deserves high commendation. But all, even those closest to the work, admit its shortcomings.

It seems that the obvious solution to a perplexing problem is the establishment of a leprosarium in the Hinterland near the source of trouble. One would immediately think of Yemen as a suitable site, but realizing the fanatical unsympathetic attitude of the Iman of Yemen the impossibility of such an event discourages every initiative in thought. Two alternatives suggest themselves:

(1) Continuance with what all admit is useful but in no sense adequately meeting the needs.

(2) Establishment of a Leprosarium within the Aden Protectorate near the Yemen border.

The latter of these two alternatives was discussed fully during interviews at the Residency both with the Frontier Secretary and the Chief Commissioner. Both expressed deep interest and sympathy provided certain conditions could be met, chief of which were :

(1) Approval of the local state.

(2) Assurance of proper police precaution against transfer of foci from present site into uncontaminated territory.

The task is no easy one. The ultimate solving of the problem can be done only by those most closely connected with the situation. The purpose of such a report is but to give impressions in the hope that some outside unprejudiced opinion may stimulate activity.

\section{Makalla and Hadramaut.}

If Aden and Yemen present problem No. 1, then Makalla and Hadramaut present problem No. 2. Here we found another definite leper area within quite definite geographical boundaries.

Here on the whole the disease seems to be self-limiting 
in that many of the cases are of the far advanced type (stage of subsidence of disease). Some were mutilated beyond hope of recovery and no longer infectious. Then there has been developed in Wadi Doan and Wadi Esar an unusual system of isolation. If we take Wadi Esar for example, we find nine small huts built outside a town to which the lepers are committed. They are then not allowed to enter the town except very occasionally. Food is brought to them by members of their own families. This method lacks much but is quite effective. Unfortunate victims are often called leprous and committed to a hut. I saw one case in Wadi Doan of a woman who was non-leprous (I was sure) and reported it to the authorities. They agreed to allow her to return to the village but it was soon evident that public opinion was so strong that she would have to return to the hut. I did not find here early cases such as I saw in Sheikh Othman coming from the Yemen area. In Wadi Hadramaut proper I found no cases.

\section{Bilad Mahara.}

The work done here was very small in amount and therefore can only be an impression. Adverse circumstances at sea forced me to spend some days at both Saihut and Gishn. I did not have my medical kit with me so I did not treat many patients, but a Doctor in Arabia is never without the sick, and soon the halt, maimed and blind all come. I did see a great number of patients but only three lepers. The people do not know the disease and there is no public horror of the same as in Wadi Doan. This I consider very significant.

\section{Dhufar.}

Dhufar Providence is an integral part of Oman Sultanate. It is, with the exception of Yemen, the most fertile part of Arabia. I spent two months here and discovered what I believe may be the beginning of a third focus of leprosy. A number of children showed signs of the disease. We did 3,439 treatments and discovered 21 positive cases, six of whom were children.

\section{Muscat and Oman.}

In Muscat and Muttrah, sister seaports of Oman, we have some twenty-five to thirty lepers; they are all beggars. Most of them are of the non-infectious type.

\section{Bahrain.}

Along with Bahrain we will consider the Pirate Coast. Here leprosy is found but does not create a specific problem. 
Bahrain lepers are found in the Baharnar villages. It is to be hoped that in the very near future the Bahrain Government will establish work among them. Along the Pirate Coast especially in the city of Dubai they isolate cases in much the same way as they do in Hadramaut. This method of isolation has its decided drawbacks because of the profound ignorance concerning the true nature of the disease that exists.

\section{Kuwait.}

Dr. Mylrea, who has spent over twenty-five years in this field, writes- " Leprosy is not one of our problems. I think I have treated only two lepers in Kuwait since 1929 (7 years)"

\section{Conclusion.}

(1) A few cases of leprosy may be found in any section of Arabia, but it is only in the southern number and nature of the disease become such as to create a concrete problem. Nejd.

(2) Leprosy is not one of the medical problems in Kuwait and

(3) Definite foci of infection are to be found in Yemen and Wadi Doan.

(4) Dhufar has possibly the beginning of a third focus of infection and should be carefully watched.

(5) The situation in Sheikh Othman does not in any sense adequately meet the situation. They are to be commended for the good work that they are doing, but I am sure those in charge would be the first to admit the shortcomings. An institution on or near the border which would not be a compromise between humanity and expediency but rather a leprasorium of high grade could then cope with the need and become a real factor in the eradication of leprosy from Yemen and the Aden Protectorate.

(6) Profoundest ignorance of leprosy exists on the part of nearly all Rulers and Government Officials and Medical Officers of the Government.

(7) A careful survey of the Yemen field should be undertaken as soon as possible.

(8) Literature and anti-leprosy propaganda should be sent to the Medical Officers of Saudia, Yemen and the Aden Governments. Their full co-operation should be enlisted. Some medical person with a knowledge of leprosy and a knowledge of the country and situation should be used as a center for such dissemination.

(9) The methods of isolation at Wadi-Doan should be studied carefully from a sociological point of view and also a study into Arab customs and nature.

(10) This survey gives ample proof that leprosy is essentially focal in its distribution and that we should concentrate on the more serious focal points in anti-leprosy campaigns. 